\title{
Comparative Study on Synthesis and Characterization of Ceria Based Composite Oxides Containing Manganese Nano-Particles
}

\author{
N.M. Deraz ${ }^{\text {a,b }}$ \\ ${ }^{a}$ Physical Chemistry Department, Laboratory of Surface \\ Chemistry and Catalysis, National Research Center, Cairo, \\ Egypt and ${ }^{b}$ Chemistry Department, College of Science, King \\ Saud University, P.O. Box 2455, Riyadh 11451, Saudi Arabia.
}

\begin{abstract}
M
$\mathrm{n} / \mathrm{Ce}$ nano-composite oxides containing different amounts of manganese $\left(5,9,17,23,29,34 \mathrm{wt} \%\right.$ as $\left.\mathrm{MnO}_{2}\right)$ were prepared by impregnation method at various calcination temperatures. Effect of both thermal treatment and loading on the structural, surface and microstructure properties of the as prepared nano-composites was determined. The combined effect of manganese oxide and ceria, at different concentrations, strongly influences the previous properties of the nano-composite oxides, by dispersing the $\mathrm{MnO}_{2}$ phase and promoting the efficiency of the $\mathrm{Ce}^{4+}-\mathrm{Ce}^{3+}$ and $\mathrm{Mn}^{4+}-\mathrm{Mn}^{3+}$ redox couples.

The thermal treatment and loading influenced the interaction between manganese and $\mathrm{CeO}_{2}$ evidently. The incorporation of $\mathrm{Mn}$ ions into $\mathrm{CeO}_{2}$ crystal lattice resulted in weaker interaction between manganese and ceria on composite surface. Manganese loading at $400^{\circ} \mathrm{C}$ led to a slight increase in the ceria crystallite size which decreased by increasing the calcination temperature from 400 to $600^{\circ} \mathrm{C}$. The sintering activation energy of ceria was evaluated to be $12 \mathrm{~kJ} / \mathrm{mol}$ for the $\mathrm{MnO}_{2} / \mathrm{CeO}_{2}$ nano-composite.
\end{abstract}

Keywords: XRD, TEM, $\mathrm{S}_{\mathrm{BET}}$ and $\mathrm{MnO}_{2} / \mathrm{CeO}_{2}$ nano-composite.

Most oxide ceramics, especially cerium oxide, are known to play an important role in many catalytic industrial processes ${ }^{(1)}$. The physicochemical properties of these oxides and their solid solution derivatives are greatly dependent upon three main factors: particle size, structural distortion and chemical nonstoichiometry ${ }^{(2)}$. In general, reducing the particle size of a catalyst solid results in increasing its surface area and changing its morphology (e.g, from large pellets to spherical clusters), thus providing a larger number of more reactive edge sites. Especially when the particle size is decreased below $100 \mathrm{~nm}$, the materials become nanophase where the density of defects increases so that up to $50 \%$ of the atoms (molecules) are situated in the cores of defects (grain boundaries, inter-phase boundaries, dislocations,... etc.). The high density of the defects in nano-phase materials provides a large number of active sites for gas-solid catalysis, while the

Fax: +2 0233370931, E-mail: nmderaz@yahoo.com 
high diffusivity through nanometer-sized inter-phase boundaries promotes fast kinetics of catalyst activation and reactions. Stoichiometric defects such as oxygen deficiency (vacancy) and its mobility on the catalyst surface are of great importance for redox gas conversions. Oxygen vacancies can be created by nonstoichiometric synthesis of the oxides of a metal which has either multiple oxidation states or partial substitution (doping) of another cation with lower oxidation state. The mobility of the oxygen vacancies increases with decreasing particle size and increasing the inter-granular layers.

Cerium dioxide, $\mathrm{CeO}_{2}$, is known to play an important role in many catalytic processes ${ }^{(2)}$. $\mathrm{CeO}_{2}$ has a fluorite-like cubic structure in which each cerium site is surrounded by eight oxygen sites in fcc arrangement and each oxygen site has a tetrahedron of cerium sites. Under various redox conditions, the oxidation state of cerium may vary between $3+$ and $4+$.

Ceria-based mixed oxides $\left(\mathrm{M}_{\mathrm{x}} \mathrm{Ce}_{1-x}\right) \mathrm{O}$ are versatile solid oxygen exchangers. At temperatures in the range of $400-800{ }^{\circ} \mathrm{C}$, the redox couple $\mathrm{Ce}^{4+} \leftrightarrow \mathrm{Ce}^{3+}$ facilitates oxygen storage and release from its bulk fluorite lattice, making it an ideal candidate for catalytic and/or electrocatalytic oxidation applications in solid oxide fuel cells (SOFCs). However, the surface redox chemistry of ceria is sensitive even at low temperatures to crystal structure defects, which can be tuned by substituting some of the Ce cations with ions of different sizes and/or charges. Substitution of a lower-valent metal ion $\left(e . g, \mathrm{M}^{3+}\right)$ by cerium lowers the energy barrier for oxygen migration ${ }^{(3)}$. However, smaller homovalent ions $\left(\mathrm{M}^{4+}\right)$ enhance the oxygen storage capacity (OSC) by decreasing the activation energy for the reduction $\left(\mathrm{Ce}^{4+} \rightarrow \mathrm{Ce}^{3+}\right)$ and retarding OSC degradation at high temperature. Given the effects of trivalent ions and smaller sizes on the structure and properties, there is considerable scientific interest in introducing $\mathrm{M}^{3+}$ ions into the ceria lattice. Ceramic methods allow the formation of such solid solutions, but the preparation temperature and time required to obtain a homogeneous mixture depends to a significant extent on the particle size of the starting material. The different properties of some oxide ceramics and their solid solution derivatives are greatly dependent upon three main factors: particle size, structural distortion and chemical non-stoichiometry ${ }^{(2)}$.

It is noted that the composition of Mn-Ce catalysts exerts a strong effect on their redox properties at low temperature ${ }^{(3,4)}$. Transition metal Mn oxides with variable valence states can store and release oxygen in the same way as $\mathrm{CeO}_{2}$ and $\mathrm{Ce}_{2} \mathrm{O}_{3}$; therefore, they may be oxygen storage materials, which are main components for automotive exhaust catalyst. It is possible for $\mathrm{Ce}-\mathrm{Mn}-\mathrm{O}$ composite oxides to be a great potential as additives to three- way catalyst.

The mixed Mn-Ce-O oxides were studied in many interesting fields. Mn-Ce composite oxides have been found to be remarkably active in the sub-critical wet oxidation of several refractory pollutants, such as ammonia, acetic acid, pyridine, phenol and polyethylene glycol ${ }^{(5)}$. It is well established that the preparation

Egypt. J. Chem. 53, No.1 (2010) 
method could exert a basic influence on the physicochemical properties of ceriabased mixed oxides, like surface area, component dispersion and strength of interaction, which in turn determines the redox properties and reactivity of the final product ${ }^{(6)}$. It has been well accepted that the interactions between $\mathrm{MnO}_{x}$ and $\mathrm{CeO}_{2}$ vary with composition, resulting in the evolution of textural, structural, and oxidation state ${ }^{(7)}$.

Manganese-cerium composite oxides with different molar ratio $\mathrm{Mn} /(\mathrm{Mn}+\mathrm{Ce})$ $(0,0.25,0.50,0.75,1)$ were prepared by citric acid method and investigated concerning their adsorption behaviour, redox properties and behaviour in the selective catalytic reduction of $\mathrm{NO}_{\mathrm{x}}$ by $\mathrm{NH}_{3}{ }^{(4)}$. The studies based on pulse thermal analysis combined with mass spectroscopy and FT-IR spectroscopy uncovered a clear correlation between the dependence of these properties and the mixed oxide composition. The highest activity to nitrogen formation was found for composites with a molar ratio $\mathrm{Mn} /(\mathrm{Mn}+\mathrm{Ce})$ of 0.25 , whereas the activity was much lower for the pure constituent oxides. Yasyerli et al. ${ }^{(8)}$ argued for the formation of Mn-Ce-O solid solutions and observed shift in the lattice parameter of ceria on ceriummanganese composite oxides containing different molar ratios of $\mathrm{Ce} / \mathrm{Mn}$. They concluded that the high reducibility and catalytic activity of the mixed oxides were associated with strong interactions between $\mathrm{Mn}$ and $\mathrm{Ce}$.

In order to improve the structural and morphological properties of these materials, we used the impregnation method to prepare new samples with varying $\mathrm{Mn} / \mathrm{Ce}$ ratio in the entire compositional range at different calcination temperatures. This procedure allows an excellent control over relevant properties of the synthesized materials, namely compositional homogeneity, purity, and surface area. In this work, the samples were characterized by different techniques.

\section{Experimental}

\section{Composite preparation}

Various $\mathrm{MnO}_{2} / \mathrm{CeO}_{2}$ composite samples were prepared by impregnating a known weight of finely powdered ceria solid with calculated amounts of manganese dissolved in the least amount of distilled water enough to make a paste. The paste containing manganese was dried at $100^{\circ} \mathrm{C}$ until constant weight and was then subjected to heat treatment for $4 \mathrm{hr}$ at $400{ }^{\circ} \mathrm{C}$, respectively. The manganese concentrations were 5, 9, 17, 23, 29 and $34 \mathrm{wt} \%$ as $\mathrm{MnO}_{2}$. Additional samples were prepared by heating the paste containing $17 \mathrm{wt} \% \mathrm{MnO}_{2}$ for $4 \mathrm{hr}$ at 500 and $600{ }^{\circ} \mathrm{C}$. The chemicals employed were of analytical grade and supplied by BDH Company.

\section{Composite characterization}

An X-ray measurement of various mixed solids was carried out using a BRUKER D8 advance difractometer. The patterns were run with $\mathrm{Cu} \mathrm{K}_{\alpha}$ radiation at $40 \mathrm{kV}$ and $40 \mathrm{~mA}$ with scanning speed in $2 \theta$ of $2^{\circ} \mathrm{min}^{-1}$. 
The crystallite size of $\mathrm{CeO}_{2}$ phase present in the investigated solids was based on X-ray diffraction line broadening and calculated by using Scherrer equation ${ }^{(9)}$.

$$
\mathrm{D}=\frac{\mathrm{B} \lambda}{\beta \cos \theta}
$$

where $\mathrm{D}$ is the mean crystallite size of the phases under investigation, $\mathrm{B}$ is the Scherrer constant (0.89), $\lambda$ is the wave length of X-ray beam used, $\beta$ is the fullwith half maximum (FWHM) of diffraction and $\theta$ is the Bragg's angle.

Transmission electron micrographs (TEM) were recorded on JEOL TEM1230 electron microanalysis. The samples were dispersed in ethanol and then treated ultrasonically in order to disperse individual particles over a gold grids.

\section{Surface characteristics}

The surface characteristics of various solid catalysts, namely, the specific surface area $\left(\mathrm{S}_{\mathrm{BET}}\right)$, total pore volume $\left(\mathrm{V}_{\mathrm{p}}\right)$ and mean pore radius (í) were determined from nitrogen adsorption isotherms measured at $-196{ }^{\circ} \mathrm{C}$, using Nova 2000, Quanta Chrome (commercial BET unit). Before undertaking such measurements, each sample was degassed under a reduced pressure of $10^{-5}$ Torr for $2 \mathrm{hr}$ at $200{ }^{\circ} \mathrm{C}$.

\section{Results}

\section{Structural analysis}

XRD examination of $\mathrm{MnO}_{2} / \mathrm{CeO}_{2}$ composites, containing 5, 9, 17, 23, 29 and $34 \mathrm{wt} \% \mathrm{MnO}_{2}$, calcined at $400{ }^{\circ} \mathrm{C}$ for $4 \mathrm{hr}$ revealed a nano-crystalline nature for the bulk structure. The crystalline phase compositions identified are shown in Fig. 1. Inspection of this figure showed the following: (i) the diffraction patterns of each sample evidenced the nanocrystalline $\mathrm{CeO}_{2}$ phase was observed. The ceria is cubic system with space group $F m 3 m$. The diffraction of the 4-29 wt \% $\mathrm{MnO}_{2} / \mathrm{CeO}_{2}$ samples calcined at $400{ }^{\circ} \mathrm{C}$ includes all the diffraction peaks of $\mathrm{CeO}_{2}$ with the absence of $\mathrm{MnO}_{2}$ peaks depending on the amount of $\mathrm{MnO}_{2}$ in these samples which is very small beyond the detection limit of X-ray diffraction. This observation suggests fine dispersion of $\mathrm{MnO}_{2}$ on the surface of ceria and/or Mn-Ce-O solid solution formation ${ }^{(8)}$. (ii) The X-ray diffractograms of 34 wt $\% \mathrm{MnO}_{2} / \mathrm{CeO}_{2}$ sample subjected to heating at $400{ }^{\circ} \mathrm{C}$ showed that this sample consisted of all diffraction peaks of $\mathrm{CeO}_{2}$ as a major phase besides some diffraction peaks of poorly crystalline $\mathrm{MnO}_{2}$ (Pyrolusite) as a minor phase ${ }^{(10)}$. (iii) $\mathrm{MnO}_{2}$ loading of the investigated system calcined at $400{ }^{\circ} \mathrm{C}$ brought about some modifications in the degree of crystallinity of the produced phases. The intensity of the (111) plane of $\mathrm{CeO}_{2}$ was considered as a measure of its degree of crystallinity. Manganese loading resulted in a progressive decrease in the degree of crystallinity of $\mathrm{CeO}_{2}$ phase as evidenced by the significant decrease in the height of all diffraction peaks of this oxide and also an increase in their width.

Egypt. J. Chem. 53, No.1 (2010) 
This decrease was more pronounced in case of the $23 \mathrm{wt} \% \mathrm{MnO}_{2} / \mathrm{CeO}_{2}$ sample. The maximum decrease in the intensity of the (111) plane of $\mathrm{CeO}_{2}$ due to loading by $23 \mathrm{wt} \% \mathrm{MnO}_{2}$ was attained $74 \%$.

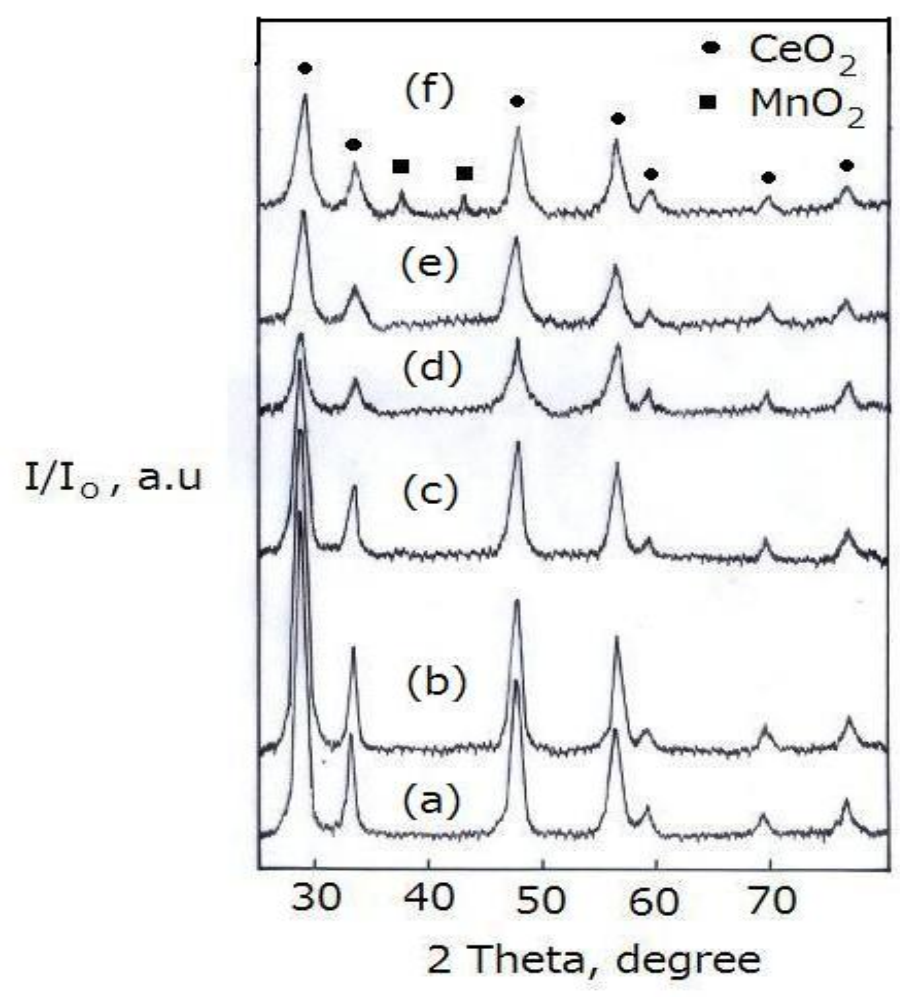

Fig. 1. X-ray diffractograms of $\mathrm{MnO}_{2} / \mathrm{CeO}_{2}$ nanocomposites calcined at $400{ }^{\circ} \mathrm{C}$. $\mathrm{MnO}_{2}$ concentrations: (a) 5; (b) 9; (c) 17; (d) 23; (e) 29 and (f) $34 \mathrm{wt} \%$.

The effects of the calcination temperature on the X-ray patterns of the $17 \mathrm{wt} \%$ $\mathrm{MnO}_{2} / \mathrm{CeO}_{2}$ sample were investigated. Figure 2 displays the X-ray diffractogram of the 17 wt $\% \mathrm{MnO}_{2} / \mathrm{CeO}_{2}$ sample calcined at 500 and $600^{\circ} \mathrm{C}$ for $4 \mathrm{hr}$. The comparison between Fig. 1 and 2 shows the following: (i) the XRD patterns of the 17 wt $\% \mathrm{MnO}_{2} / \mathrm{CeO}_{2}$ sample consisted only of all diffraction peaks of $\mathrm{CeO}_{2}$. (ii) The rise in the calcination temperature from 400 to $600{ }^{\circ} \mathrm{C}$ led to a decrease in the degree of crystallinity of $\mathrm{CeO}_{2}$ phase as evidenced by the significant decrease in the height of all diffraction peaks of this oxide and also an increase in their width. The maximum decrease in the intensity of the (111) plane of $\mathrm{CeO}_{2}$ due to heating of the $17 \mathrm{wt} \% \mathrm{MnO}_{2} / \mathrm{CeO}_{2}$ sample calcined at $600{ }^{\circ} \mathrm{C}$ attained $62.5 \%$. This indicates that the heat treatment enhanced the solubility of manganese oxide in the ceria lattices. 


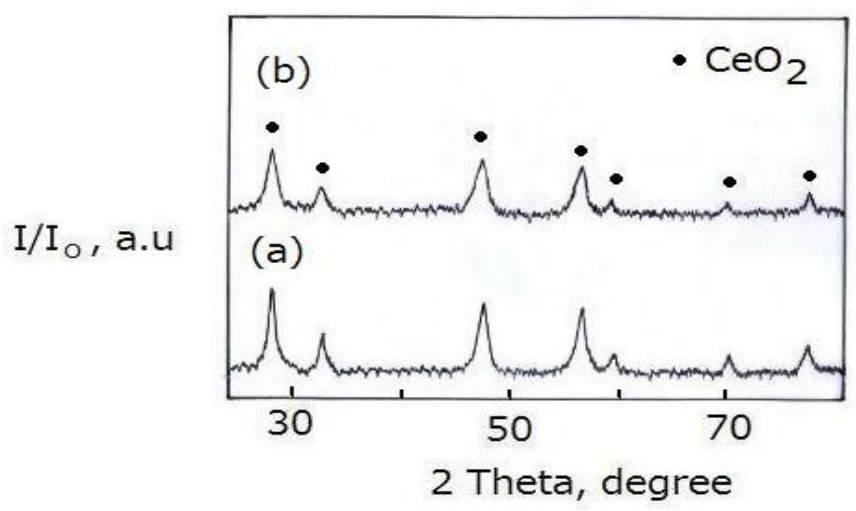

Fig. 2. X-ray diffractograms of $17 \mathrm{wt} \% \mathrm{MnO}_{2} / \mathrm{CeO}_{2}$ nanocomposites calcined at (a) 500 and (b) $600{ }^{\circ} \mathrm{C}$.

The X-ray data enabled us to investigate the effects of the calcination temperature and $\mathrm{MnO}_{2}$ loading of the system studied in modifying the lattice constant, crystal size, unit cell volume and degree of crystallinity of $\mathrm{CeO}_{2}$ phase present in various composites. The computed values of different structural parameters of $\mathrm{CeO}_{2}$ phase in different composites are given in Table 1. The careful examination of this table reveals the following: (i) $\mathrm{MnO}_{2}$ loading of the system investigated carried out at $400{ }^{\circ} \mathrm{C}$ resulted in a measurable increase in the crystallite size, lattice constant and unit cell volume of $\mathrm{CeO}_{2}$ phase depending upon the amount of $\mathrm{MnO}_{2}$ added. The addition of $23 \mathrm{wt} \% \mathrm{MnO}_{2}$ to the system investigated brought about an increase of 19.2, 1.7 and $0.6 \%$ in the crystallite size, lattice constant and unit cell volume of $\mathrm{CeO}_{2}$ phase, respectively. (ii) The augmentation in calcination temperature of the 17 wt $\% \mathrm{MnO}_{2} / \mathrm{CeO}_{2}$ composite from 400 to $600{ }^{\circ} \mathrm{C}$ brought about a significant decrease in the crystallite size, lattice constant and unit cell volume of $\mathrm{CeO}_{2}$ phase. The maximum decrease attained $38.5,1.5$ and $0.4 \%$ in the crystallite size, lattice constant and unit cell volume of $\mathrm{CeO}_{2}$ phase, respectively, due to heating the 17 wt $\% \mathrm{MnO}_{2} / \mathrm{CeO}_{2}$ composite at $600{ }^{\circ} \mathrm{C}$. (iii) The values of crystallite size of $\mathrm{CeO}_{2}$ crystallite present in the investigated composites calcined at $400-600{ }^{\circ} \mathrm{C}$ enabled the calculation of sintering activation energy $\left(\Delta \mathrm{E}_{\mathrm{s}}\right)$ of this oxide using Arrhenius equation, this was found to be $12 \mathrm{~kJ} / \mathrm{mol}^{(11)}$.

The observed structural modifications of $\mathrm{CeO}_{2}$ phase due to heat treatment and/or loading of $\mathrm{MnO}_{2} / \mathrm{CeO}_{2}$ system with different amounts of $\mathrm{MnO}_{2}$ can be discussed in terms of dissolution of some manganese species in $\mathrm{CeO}_{2}$ lattice. The dissolution process may lead to the formation of new chemical compounds and/or solid solutions ${ }^{(10)}$. The dissolution of $\mathrm{MnO}_{2}$ in the outermost surface of ceria led to conversion of some $\mathrm{Ce}^{4+}$ ions, present in non-stoichiometric $\mathrm{CeO}_{2}$, into $\mathrm{Ce}^{3+}$ ions with subsequent increase in the value of its lattice constant. On the contrary, the inhibiting effect might be due to the diffusion of $\mathrm{MnO}_{2}$ into the interior of ceria grains by the heat treatment.

Egypt. J. Chem. 53, No.1 (2010) 
TABLE 1. The effects of heat treatment and $\mathrm{MnO}_{2}$ loading on some structural parameters of cerium oxide involved in $\mathrm{MnO}_{2} / \mathrm{CeO}_{2}$ nanocomposite.

\begin{tabular}{|c|c|c|c|c|c|c|}
\hline $\begin{array}{c}\text { Concentration } \\
\text { of } \\
\mathbf{M n O}_{\mathbf{2}}(\mathbf{w t} \%)\end{array}$ & $\begin{array}{c}\text { Calcin. } \\
\text { Temp. } \\
\left({ }^{\mathbf{o}} \mathbf{C}\right)\end{array}$ & $\begin{array}{c}\mathbf{D} \\
(\mathbf{n m})\end{array}$ & $\begin{array}{c}\mathbf{a} \\
(\mathbf{n m})\end{array}$ & $\begin{array}{c}\mathbf{V} \\
\left(\mathbf{n m}^{\mathbf{3}}\right)\end{array}$ & $\begin{array}{c}\text { Degree of } \\
\text { crystallinity } \\
(\mathbf{a . u})\end{array}$ & $\begin{array}{c}\text { Crystalline } \\
\text { composition }^{\mathbf{a}}\end{array}$ \\
\hline 5 & 400 & 15.6 & 0.5403 & 0.1577 & 59 & $\mathrm{CeO}_{2}$ \\
9 & 400 & 16 & 0.5408 & 0.1582 & 57 & $\mathrm{CeO}_{2}$ \\
17 & 400 & 17.9 & 0.5414 & 0.1587 & 40 & $\mathrm{CeO}_{2}$ \\
& 500 & 15 & 0.5409 & 0.1583 & 17 & $\mathrm{CeO}_{2}$ \\
23 & 600 & 11 & 0.5406 & 0.1580 & 15 & $\mathrm{CeO}_{2}$ \\
29 & 400 & 18.6 & 0.5434 & 0.1605 & 16 & $\mathrm{CeO}_{2}$ \\
34 & 400 & 16.8 & 0.5414 & 0.1587 & 28 & $\mathrm{CeO}_{2}$ \\
& 400 & 16 & 0.5412 & 0.1586 & 33 & $\mathrm{CeO}_{2}(\mathrm{~d}, \mathrm{j})$ \\
& & & & & & $\mathrm{and}_{2}(\mathrm{~m})$ \\
\hline
\end{tabular}

a d: dominant, j: major, m: minor.

\section{TEM analysis}

The micro structural evolution during the heat treatment and loading of $\mathrm{MnO}_{2} / \mathrm{CeO}_{2}$ composite samples are shown in Fig. 3. Figure (3A-C) shows the effect of loading by 5, 17 and 34 wt $\% \mathrm{MnO}_{2}$ on the formation of $\mathrm{MnO}_{2} / \mathrm{CeO}_{2}$ composite particles under impregnation conditions. It shows agglomeration of ultra fine particles with rod-like structures. These samples are revealed to be assembled by randomly oriented spherical nano-crystallites. The population size distribution calculated from TEM images shows the particle diameter for $\mathrm{MnO}_{2} / \mathrm{CeO}_{2}$ composites calcined at $400{ }^{\circ} \mathrm{C}$ of about $15-18 \mathrm{~nm}$. When the ceria has been modified with increasing amounts of manganese oxide, we can find that the surface of spherical crystallites is covered very uniformly with highly ordered array. However, the manganese loading resulted in a slight increase in the particle size of the investigated solids indicating the formation of $\mathrm{Mn}-\mathrm{Ce}-\mathrm{O}$ solid solution at the composite surface. Fig. 3(D \& E) displays the effect of heat treatment at 500 and $600^{\circ} \mathrm{C}$ on the morphology of loading by 17 wt $\%$ $\mathrm{MnO}_{2} / \mathrm{CeO}_{2}$ composite systems.

The comparison between TEM images in Fig. 3(B, D) and E shows the following: (i) the rise in the calcination temperature from 400 to $500{ }^{\circ} \mathrm{C}$ brought about tree leaves like particle composed of spherical and uniform crystallites. Increasing the preparation temperature from 500 to $600^{\circ} \mathrm{C}$ led to week agglomeration of the nanoparticles. (ii) The heat treatment resulted in a decrease in the particle size of the investigated composite. In fact, the solid calcined $600^{\circ} \mathrm{C}$ as shown in Fig. 3E showed the smallest crystallite size of diameter about $11 \mathrm{~nm}$. In other words, the heat treatment and $\mathrm{MnO}_{2}$ loading brought about a decrease in the particle size of $\mathrm{MnO}_{2} / \mathrm{CeO}_{2}$ composite. These findings suggest incorporation of manganese species in the ceria lattices indicating the contraction in the ceria lattice with subsequent decrease in the solid state reaction between $\mathrm{MnO}_{2}$ and $\mathrm{CeO}_{2}$ forming $\mathrm{Mn}-\mathrm{Ce}-\mathrm{O}$ solid solution at the composite surface. Moreover, the stimulation effect towards the solubility of manganese species in the ceria crystal was more pronounced by heat treatment. 

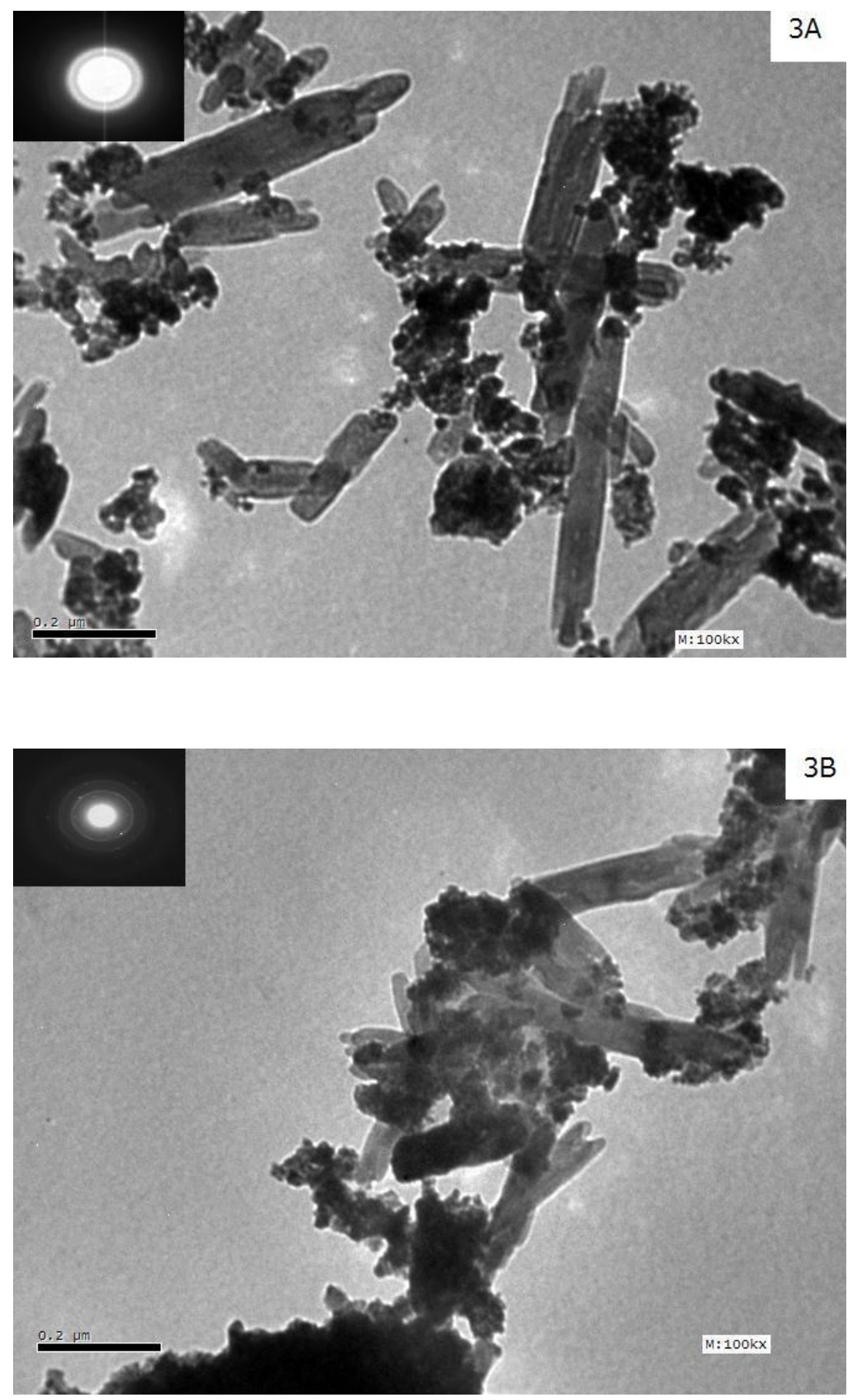

Egypt. J. Chem. 53, No.1 (2010) 

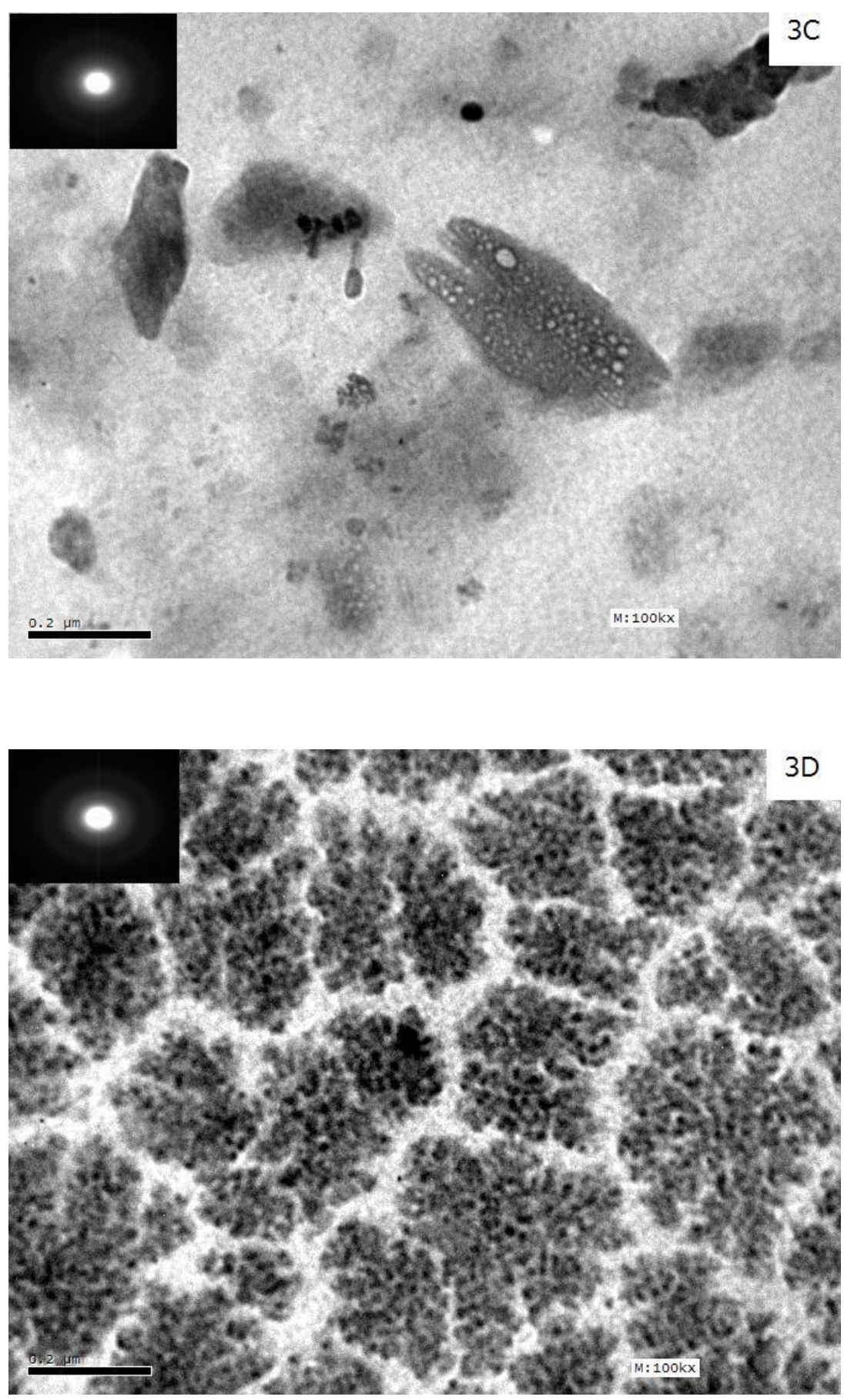

Egypt. J. Chem. 53, No.1 (2010) 


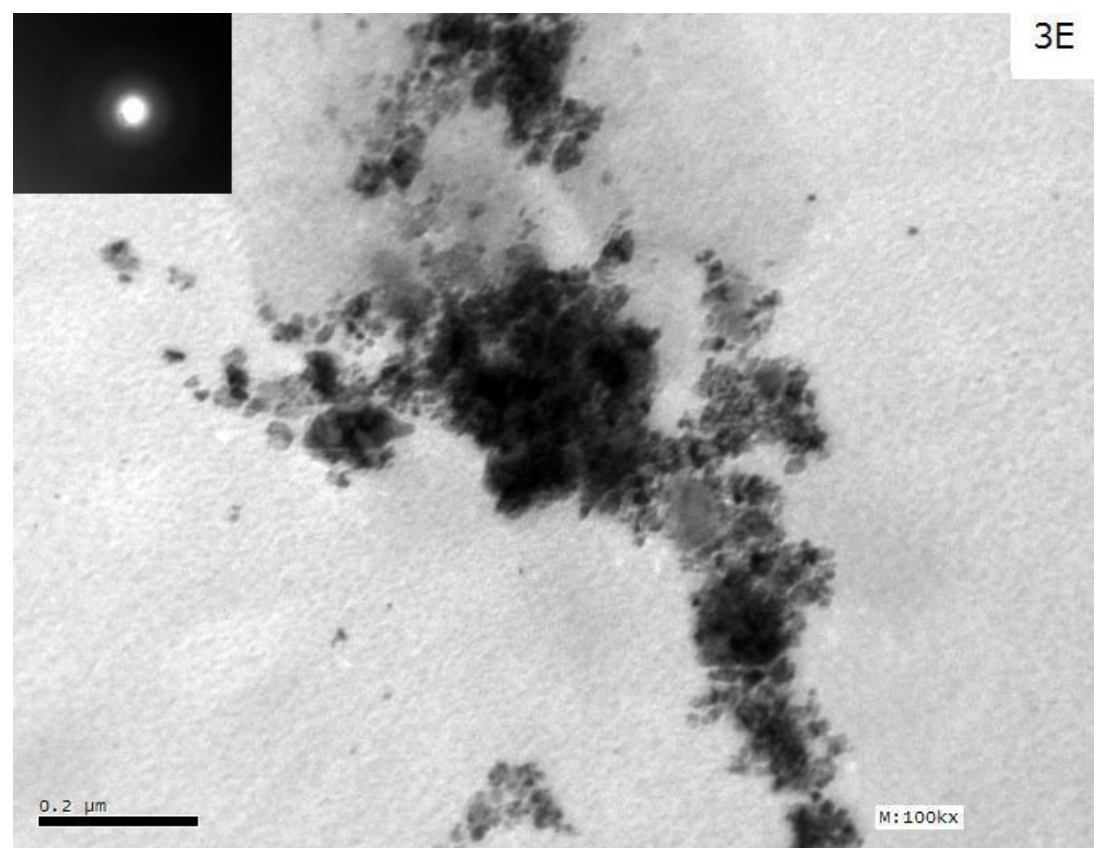

Fig. 3. TEM images of various $\mathrm{MnO}_{2} / \mathrm{CeO}_{2}$ nanocomposites: (A) $5 \mathrm{wt} \% \mathrm{MnO}_{2} / \mathrm{CeO}_{2}$ calcined at $400{ }^{\circ} \mathrm{C}$, (B) $17 \mathrm{wt} \% \mathrm{MnO}_{2} / \mathrm{CeO}_{2}$ calcined at $400{ }^{\circ} \mathrm{C}$, (C) $34 \mathrm{wt} \%$ $\mathrm{MnO}_{2} / \mathrm{CeO}_{2}$ calcined at $400{ }^{\circ} \mathrm{C}$, (D) $17 \mathrm{wt} \% \mathrm{MnO}_{2} / \mathrm{CeO}_{2}$ calcined at $500{ }^{\circ} \mathrm{C}$ and $(\mathrm{E}) 17 \mathrm{wt} \% \mathrm{MnO}_{2} / \mathrm{CeO}_{2}$ calcined at $600{ }^{\circ} \mathrm{C}$.

To complete the information, the electronic micro-diffraction was used to determine the chemical structure of the small grains. The corresponding selected area electron diffraction (SAED) patterns of the mentioned samples are shown in Fig. 3(A-E). All the diffraction spots corresponding to aggregates are generally distributed on circles. Whatever the sample, the circles related to the microdiffraction of $\mathrm{CeO}_{2}$ are continuous in agreement with the homogeneity of the $\mathrm{CeO}_{2}$ grains observed in TEM images. The ring-type diffraction pattern shown in Fig. 3(A-E) is indexed to polycrystalline $\mathrm{CeO}_{2}$ in fluorite structure.

\section{Surface Characteristics}

The surface properties of the various investigated solids determined from nitrogen adsorption isotherm measured at $-196{ }^{\circ} \mathrm{C}$ are given in Table 2 . The data in this table demonstrate the effects of manganese content and calcination temperature on the different surface properties of the investigated mixed solids. Representative adsorption/desorption isotherms for nitrogen on $17 \mathrm{wt} \%$ $\mathrm{MnO}_{2} / \mathrm{CeO}_{2}$ composite sample calcined at $400-600{ }^{\circ} \mathrm{C}$ are depicted in Fig. 4. All the isotherms displayed common characteristics, being similar in the shape to type II of Brunauer's classification ${ }^{(12)}$. 
TABLE 2 . The surface properties of $\mathrm{Mn} / \mathrm{Ce}$ nano-composite catalysts containing different amounts of manganese oxide.

\begin{tabular}{|c|c|c|c|c|}
\hline $\begin{array}{c}\text { Concentration } \\
\text { of } \\
\mathbf{M n O}_{\mathbf{2}}(\mathbf{w t} \%)\end{array}$ & $\begin{array}{c}\text { Calcin. Temp. } \\
\left({ }^{\mathbf{0}} \mathbf{C}\right)\end{array}$ & $\mathbf{S}_{\mathbf{B E T}}\left(\mathbf{m}^{\mathbf{2}} / \mathbf{g}\right)$ & $\mathbf{V}_{\mathbf{p}}\left(\mathbf{c m}^{\mathbf{3}} / \mathbf{g}\right)$ & $(\mathbf{n m}) \mathbf{r}$ \\
\hline 5 & 400 & 34 & 0.0768 & 1.91 \\
9 & 400 & 40 & 0.0869 & 1.91 \\
17 & 400 & 46 & 0.0877 & 1.91 \\
& 500 & 35 & 0.0603 & 1.91 \\
& 600 & 29 & 0.0557 & 1.91 \\
23 & 400 & 52 & 0.0881 & 1.91 \\
29 & 400 & 57 & 0.0899 & 1.91 \\
34 & 400 & 61 & 0.0909 & 1.91 \\
\hline
\end{tabular}

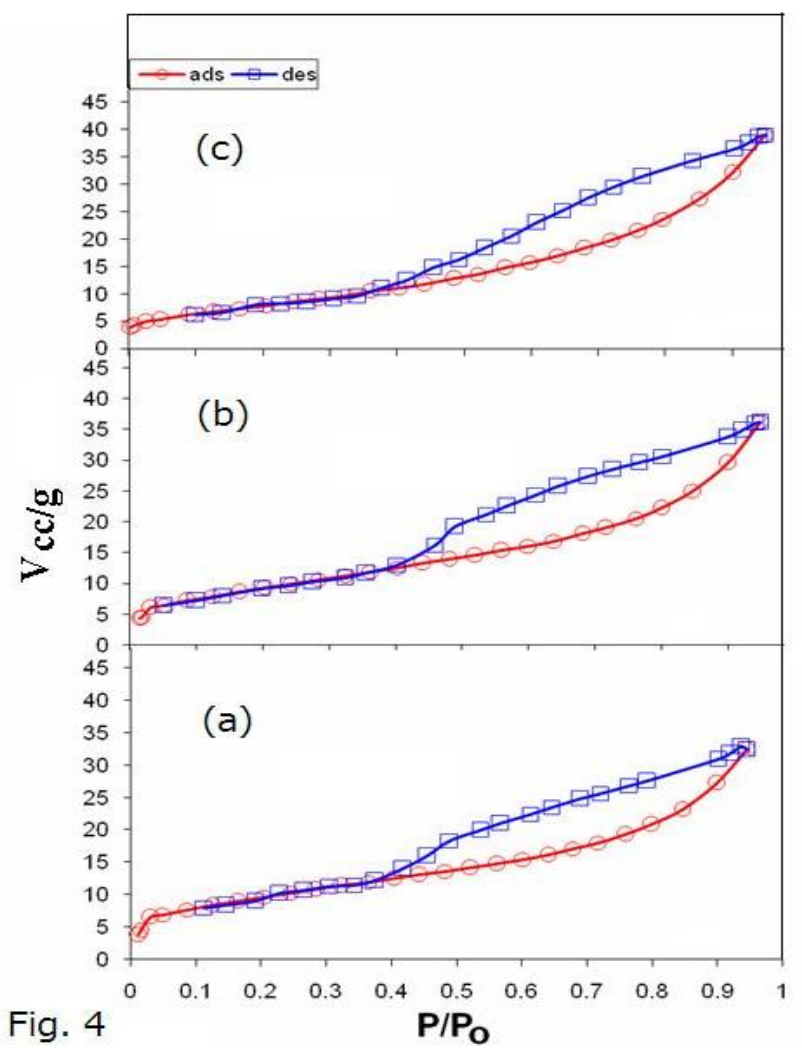

Fig. 4. $\mathrm{N}_{2}$ adsorption/desorption isotherms for $17 \mathrm{wt} \% \mathrm{MnO}_{2} / \mathrm{CeO}_{2}$ nanocomposites calcined at (a) 400, (b)500 and (c) $600{ }^{\circ} \mathrm{C}$.

Egypt. J. Chem. 53, No.1 (2010) 
It is seen from Table 2 that the $S_{\mathrm{BET}}$ values for $17 \mathrm{wt} \% \mathrm{MnO}_{2} / \mathrm{CeO}_{2}$ composite decreased as the calcination temperature was increased from 400 to $600{ }^{\circ} \mathrm{C}$. However, the loading process resulted in an increase $(79.4 \%)$ in the $S_{\mathrm{BET}}$ value of $\mathrm{Mn} / \mathrm{Ce}$ nanocomposite oxides calcined at $400{ }^{\circ} \mathrm{C}$.

The increase in the $S_{\mathrm{BET}}$ values for the investigated oxides calcined at $400{ }^{\circ} \mathrm{C}$ may be explained in terms of the following: (i) The creation of new pores resulting from the liberation of gaseous nitrogen oxides during the thermal dissociation of manganese and cerium nitrates ${ }^{(13)}$. (ii) The augmentation in the total pore volume of $\mathrm{Mn} / \mathrm{Ce}$ nanocomposite oxides.

The decrease in the $S_{\mathrm{BET}}$ values for $17 \mathrm{wt} \% \mathrm{MnO}_{2} / \mathrm{CeO}_{2}$ composite calcined in air at 400- $600{ }^{\circ} \mathrm{C}$ may be discussed in terms of the following: (i) Sintering of the mixed oxides due to the aggregation of $\mathrm{Mn} / \mathrm{Ce}$ ions via increasing of their mobility ${ }^{(13)}$. (ii) The decrease in the total pore volume of $\mathrm{Mn} / \mathrm{Ce}$ nanocomposite oxides.

\section{Discussion}

The addition of manganese oxides to the ceria surface resulted in some modifications in the structural, surface and morphological properties of the final product. At low metal content, metal species diffuse into the fluorite forming a solid solution with ceria and also metal oxide highly dispersed on $\mathrm{CeO}_{2}$ surface. At high metal content, solid solution, crystallized metal oxide and highly dispersed metal oxide phases on ceria are co-existing. The ability of ceria based materials to reversibly accept or contribute oxygen to its surroundings is the basis for its use in catalytic applications, where redox processes are important. The exact nature of the activity of cerium-based oxides depends primarily on the nature and concentration of defects in the material (e.g. oxygen vacancies, $\mathrm{Ce}^{3+}$ centres and dopants ). When oxygen vacancies are present, oxygen ions can move through the lattice relatively easily giving rise to high-oxygen ion conductivity $^{(14)}$. This also plays an important role in catalytic applications because oxygen vacancies can move rapidly from surface to bulk and vice versa. Identifying the most active phases and understanding the phase changes taking place under a certain treatments is critical to develope improved catalysts.

The observed structural modifications of $\mathrm{CeO}_{2}$ phase due to loading of ceria based system with different amounts of manganese oxides can be discussed in terms of dissolution of some of these oxides in $\mathrm{CeO}_{2}$ lattice. The dissolution process may lead to the formation of new chemical compounds and/or solid solutions ${ }^{(11)}$. Ceria can dissolve various amounts of $\mathrm{MnO}_{2}$ added. The dissolution of these oxides can take place via substituting some of host cerium ions in cerium oxide lattice by the cations added. The dissolution process in case of $\mathrm{MnO}_{2}$ loading can be simplified adoping Kroger's notions according to ${ }^{(15)}$ :

$$
\begin{aligned}
& \mathrm{MnO}_{2}+2 \mathrm{Ce}^{4+} \rightarrow \mathrm{Mn}_{\Delta}+2 \mathrm{Ce}^{3+}+1 / 2 \mathrm{O}_{2} \\
& \mathrm{MnO}_{2}+2 \mathrm{Ce}^{4+} \rightarrow \mathrm{Mn}\left(\mathrm{Ce}^{3+}\right)+2 \mathrm{Ce}^{3+}+1 / 2 \mathrm{O}_{2} \\
& \mathrm{MnO}_{2}+\mathrm{Ce}^{4+} \rightarrow \mathrm{Mn}\left(\mathrm{Ce}^{4+}\right)+\mathrm{Ce}^{4+}+\text { A. V }
\end{aligned}
$$

Egypt. J. Chem. 53, No.1 (2010) 
where $\mathrm{Ce}^{3+}$ denotes to trivalent cerium ion present in nonstoichiometric $\mathrm{CeO}_{2}$ lattice as lattice defects; $\mathrm{Mn}\left(\mathrm{Ce}^{3+}\right)$ and $\mathrm{Mn}\left(\mathrm{Ce}^{4+}\right)$ are tri- and tetravalent manganese ion located in the position of tetravalent and trivalent cerium ions of cerium oxide, receptivity; $\mathrm{Mn}_{\Delta}$ is manganese ion located in the interstitial positions of cerium oxide lattices; A.V. created anionic vacancies. The incorporation of $\mathrm{Mn}^{4+}$ in the lattice of $\mathrm{CeO}_{2}$ according to the mechanism represented by reactions (2) and (3) is accompanied by conversion of some tetravalent cerium ions into trivalent cerium ions with subsequent removal of some of excess oxygen present in non-stoichiometric $\mathrm{CeO}_{2}$ solid leaving oxygen vacancies. This observed, experimentally, via increasing of $\mathrm{Mn}$ content resulted in an increase in the total pore volume of the mixed solids calcined at $400{ }^{\circ} \mathrm{C}$ indicating the increase in their surface area.

So, loading of cerium oxide by $\mathrm{MnO}_{2}$ taking place according to reactions (2) and (3) should be accompanied by a decrease in the oxidation state of cerium ion in $\mathrm{CeO}_{2}$ via conversion of some of $\mathrm{Ce}^{4+}$ into $\mathrm{Ce}^{3+}$ with subsequent expansion in the ceria lattice. This process is normally accompanied by an increase in the lattice constant of $\mathrm{CeO}_{2}$ which has been found experimentally. In fact, $\mathrm{MnO}_{2}$ loading at $400{ }^{\circ} \mathrm{C}$ resulted in a slight increase in the particle size of ceria solid. In addition, the $\mathrm{MnO}_{x}$ deposits coexist in intimate contact with $\mathrm{CeO}_{2}$ crystallites, favouring oxygen transfer between the two metal oxides. This type of $\mathrm{MnO}_{x} / \mathrm{CeO}_{2}$ structure interaction led to an increase in the formation of the $\mathrm{Ce}_{2} \mathrm{O}_{3}$ phase. This indicated that there existed a synergistic mechanism between the manganese and cerium oxides. The proposed mechanism in this case is as follows:

$$
\begin{aligned}
& 2 \mathrm{MnO}_{2} \rightarrow \mathrm{Mn}_{2} \mathrm{O}_{3}+1 / 2 \mathrm{O}_{2} \\
& \mathrm{Mn}_{2} \mathrm{O}_{3}+2 \mathrm{CeO}_{2} \rightarrow 2 \mathrm{MnO}_{2}+\mathrm{Ce}_{2} \mathrm{O}_{3} \\
& \mathrm{Ce}_{2} \mathrm{O}_{3}+1 / 2 \mathrm{O}_{2} \rightarrow 2 \mathrm{CeO}_{2}
\end{aligned}
$$

It is well known that $\mathrm{Ce}_{2} \mathrm{O}_{3}$ can be easily re-oxidized to $\mathrm{CeO}_{2}$ by exposure to air. On the other hand, the dissolution of manganese ions in the lattices of reacting oxides according to reaction (4) which led to creation of anionic vacancies might increase the mobility of cations of reacting oxides thus enhancing the formation of Mn-Ce-O solid solution. But, the incorporation of $\mathrm{Mn}$ species in the ceria lattice brought about a decrease in the ceria lattice parameter with subsequent decrease in the particle size due to the smaller ionic radius of $\mathrm{Mn}$ than that of $\mathrm{Ce}$ ions. Indeed, the heat treatment of $17 \mathrm{wt} \%$ $\mathrm{MnO}_{2} / \mathrm{CeO}_{2}$ composite sample at $600{ }^{\circ} \mathrm{C}$ led to a decrease in the particle size of ceria crystallites. However, the diffraction lines related the manganese phase were undetected in the XRD patterns for all samples studied except presence of trace amount of $\mathrm{MnO}_{2}$ phase in case of the $34 \mathrm{wt} \% \mathrm{MnO}_{2} / \mathrm{CeO}_{2}$ sample.

These observations suggest that $\mathrm{MnO}_{2}$ loading at $400{ }^{\circ} \mathrm{C}$ led to a formation of solid solution between the manganese and cerium oxides at the composite surface, while an increase of the calcination temperature from 400 to $600{ }^{\circ} \mathrm{C}$ brought about incorporation of manganese species in the ceria lattice with subsequent migration of these species from the surface of composite to its bulks. 


\section{Conclusions}

The following are the main conclusions that may be drawn from the results obtained in the present work:

1. Ceria based composites containing different amounts of manganese oxide prepared by impregnation method and calcined at $400-600{ }^{\circ} \mathrm{C}$ consisted of nanocrystalline solids as shown in XRD and TEM measurements.

2. Increasing the amount of manganese oxide brought about a decrease in the degree of crystallinity with subsequent increase in particle size, and lattice parameter, unit cell volume of ceria over $\mathrm{Mn} / \mathrm{Ce}$ composite oxides indicating the formation of $\mathrm{Mn}-\mathrm{Ce}-\mathrm{O}$ solid solution via interaction between the manganese species and ceria.

3. The heat treatment of the $\mathrm{MnO}_{2} / \mathrm{CeO}_{2}$ composite resulted in a decrease in the degree of crystallinity, particle size, and lattice parameter, unit cell volume of ceria present.

4. The sintering activation energy of the $\mathrm{MnO}_{2} / \mathrm{CeO}_{2}$ composite was found to be $12 \mathrm{~kJ} / \mathrm{mol}$

5. The heat treatment led to a decrease in $\mathrm{S}_{\mathrm{BET}}$ of $\mathrm{Mn} / \mathrm{Ce}$ composite oxides while an increase of the manganese content brought about an increase in the $S_{\mathrm{BET}}$ value.

\section{References}

1. Alessandro Trovarelli, Carla de Leitenburg, Marta Boaro and Giuliano Dolcetti, The utilization of ceria in industrial catalysis. Catalysis Today , 50 , 353 (1999).

2. Yu Zhang, Sara Andersson and Mamoun, M., Nanophase catalytic oxides: I. Synthesis of doped cerium oxides as oxygen storage promoters. Appl. Catal. B; 6, 325 (1995).

3. Imamura, S., Okumura, Y. and Nishio, T., Utani Kazunori. Wet-oxidation of a model domestic wastewater on a $\mathrm{Ru} / \mathrm{Mn} / \mathrm{Ce}$ composite catalyst. Ind. Eng. Chem. Res. 37,1136 (1998).

4. Eigenmann, F., Maciejewski, M. and Baiker, A., Selective reduction of $\mathrm{NO}$ by $\mathrm{NH}_{3}$ over manganese-cerium mixed oxides: Relation between adsorption, redox and catalytic behaviour. Appl. Catal. B; 62, 311 (2006).

5. FaïÇal Larachi, Jèrôme Pierre, Alain Adnot and Alain Bernis, Ce 3d XPS study of composite $\mathrm{Ce}_{\mathrm{x}} \mathrm{Mn}_{1-\mathrm{x}} \mathrm{O}_{2-\mathrm{y}}$ wet oxidation catalysts. Appl. Surf. Sci. 195, 236 (2002).

6. Hongyan, L.I.N., Zhiqiang, M.A., Ding Ling, Qiu Jieshan and Changhai Liang, Preparation of nanoscale $\mathrm{Ce}_{x} \mathrm{Fe}_{1-x} \mathrm{O}_{2}$ solid solution catalyst by the template method and its catalytic properties for ethanol steam reforming. Chin. J. Catal. 29 (5), 418 (2008).

7. Limin, S.H.I., Wei, C.H.U. , Fenfen, Q.U., Jinyan, H.U. and Minmin, L.I., Catalytic performance for methane combustion of supported Mn-Ce mixed oxides. Journal of Rare Earths , 26 (6), 836 (2008).

Egypt. J. Chem. 53, No.1 (2010) 
8. Sena Yasyerli, Cerium-manganese mixed oxides for high temperature $\mathrm{H}_{2} \mathrm{~S}$ removal and activity comparisons with $\mathrm{V}-\mathrm{Mn}, \mathrm{Zn}-\mathrm{Mn}, \mathrm{Fe}-\mathrm{Mn}$ sorbents. Chemical Engineering and Processing , 47, 577 (2008) .

9. Cullity, B.D., Elements of X-ray Diffraction, (Chapter 14) Addison-Wesly Publishing Co. Inc. (1976).

10. Xiaodong, Wu, Qing Liang, Duan Weng, Jun Fan and Rui Ran, Synthesis of $\mathrm{CeO}_{2}-\mathrm{MnO}_{\mathrm{x}}$ mixed oxides and catalytic performance under oxygen-rich condition. Catal. Today, 126 , 430 (2007).

11. Tianshu Zhang, Peter Hing, Haitao Huang and Kilner, J., Sintering study on commercial $\mathrm{CeO}_{2}$ powder with small amount of $\mathrm{MnO}_{2}$ doping. Mater. Lett. 57, 507 (2002).

12. Brunauer, S., The Adsorption of Gases and Vapors, p. 150. Oxford University Press, Pinceton, NJ, USA (1945).

13. Deraz, N.M., The effect of calcium doping on surface and catalytic properties of cobaltic oxide catalysts. Adsorp. Sci. Technol. 21 (3), 229 (2003).

14. Peter A. Crozier, Ruigang Wang and Renu Sharma, In situ environmental TEM studies of dynamic changes in cerium-based oxides nanoparticles during redox processes. Ultramicroscopy , 108, 1432 (2008).

15. Kröger, F.A., Chemistry of Imperfect Crystals, North-Holand, Amsterdam (1964) .

( Received 16/11/2009;

accepted 14/ 1/2010) 


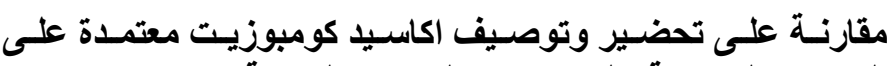

السيريا والمحتوية على جزيئات المنجنيز النانوية

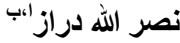

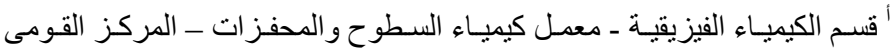

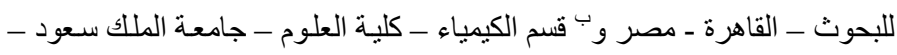

الرياض - المملكة العربية السعودية.

تم تحضير اكاسيد نانوكومبوزنيـة مـن المنجنيز و السيريوم محتويـة على كميـات

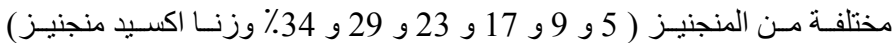

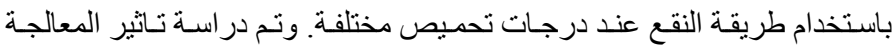

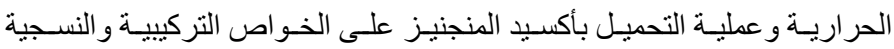

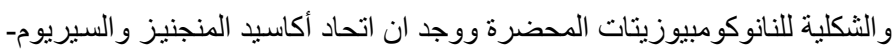

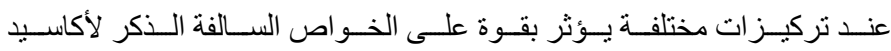

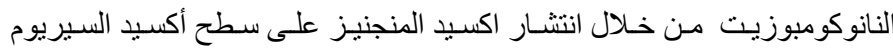

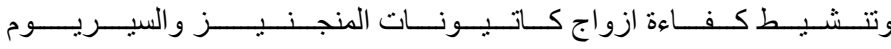
( لقد تـاثرت كل من المعالجـة الحراريـة ( $\mathrm{Ce}^{4+}-\mathrm{Ce}^{3+}$ and $\mathrm{Mn}^{4+}-\mathrm{Mn}^{3+}$ )

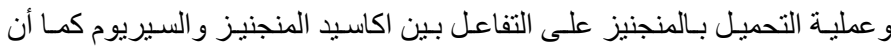

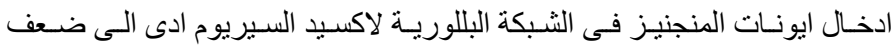

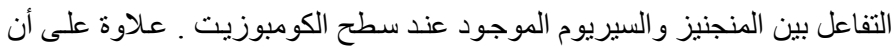

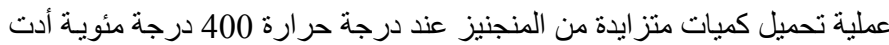

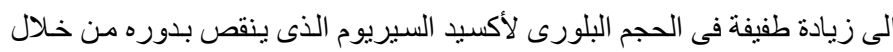

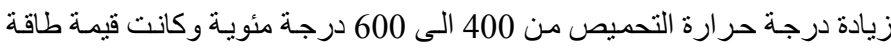

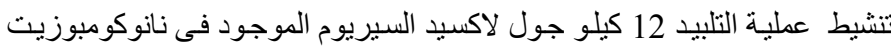
كاسيد المنجنيز و السيريوم. 
Egypt. J. Chem. 53, No.1 (2010) 